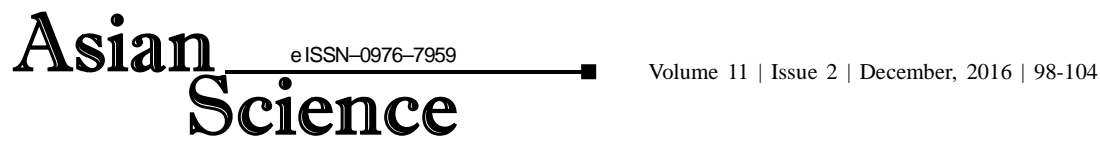

DOI : 10.15740/HAS/AS/11.2/98-104 Visit us | www.researchjournal.co.in

RESEARCH PAPER

\section{The farmer's perception about weather forecasting advisory services}

\author{
RAJESH*, S.K. MEHTA, C. D. AUTADE AND A. K. GODARA \\ Department of Extension Education, College of Agriculture, Chaudhary Charan Singh Haryana Agriculture University, \\ HISAR (HARYANA) INDIA (Email: charudattautade@gmail.com)
}

\begin{abstract}
Weather forecasting is the application of science and technology to predict the state of atmosphere for the future time and a given location. Human beings have attempted to predict the weather informally for the millennia and formally since at least the nineteenth century. Weather forecasts are made by collecting quantitative data about the current state of atmosphere and using scientific understanding of atmosphere processes to reject the atmosphere will evolve. Gibson (1959) defined PERCEPTION as the process by which an individual maintains contact with the environment. Perception is what we want to perceive from information. Perceptions vary from person to person. Different people perceive different things about the same situation. But more than that, we assign different meanings to what we perceive. It was concluded from the observation that most of the respondents had low perception level about weather forecasting advisory services in Hisar and Kaithal district. Most of the respondent had high belief in traditional weather forecasting pattern than scientific weather forecasting. The most important thing is that farmers are not interested in knowing the economic benefits of weather forecasting advisory services. It was also noticed from this survey that weather forecast advisory services will be more readily adopted if the agricultural extension services are improved. It was also observed that weather forecast affects the farmer's decision to small extent.
\end{abstract}

Key Words : Perception, Weather forecasting, Weather forecasting advisory services

View point paper : Rajesh, Mehta, S. K., Autade, C. D. and Godara, A. K. (2016). The farmer's perception about weather forecasting advisory services. Asian Sci., 11 (2): 98-104, DOI : 10.15740/HAS/AS/11.2/98-104.

\footnotetext{
* Author for correspondence

Rajesh, Department of Extension Education, College of Agriculture, Chaudhary Charan Singh Haryana Agriculture University, HISAR (HARYANA) INDIA
} 